\title{
In vitro biomass production of Sideroxylon obtusifolium (Roem \& Schult)
}

\author{
Annie Elizabeth Santiago Beltrão, ${ }^{* 1}$ Anna Cláudia de A. Tomaz, ${ }^{1}$ Fabiana Augusta S. \\ Beltrão, ${ }^{1}$ Paulo Marinho ${ }^{2}$
${ }^{1}$ Laboratório de Tecnologia Farmacêutica "Delby Fernandes de Medeiros” Universidade Federal da Paraíba, Caixa Postal 5009, 58051-970 João Pessoa-PB, Brazil,
${ }^{2}$ Departamento de Biologia e Genética Universidade Federal do Rio Grande do Norte, Caixa Postal 1656, 59078-970 Natal-RN, Brazil

\begin{abstract}
RESUMO: "Produção de biomassa in vitro de Sideroxylon obtusifolium (Roem \& Schult)". Sideroxylon obtusifolium é uma planta medicinal pertencente à família Sapotaceae que ocorre no Sudoeste e Nordeste do Brasil, utilizada por possuir propriedades antiinflamatórias e hipoglicêmicas. O uso intenso das cascas e a falta de cultivo da planta tornaram rara sua ocorrência no habitat natural. O objetivo deste estudo foi obter informações sobre a produção de biomassa desta espécie nativa utilizando as técnicas da cultura de tecidos vegetais. Foram utilizados os meios de cultura de Murashige \& Skoog (1962) e o de Gamborg et al. (1968) adicionados de auxina 2,4-diclorofenoxiacético e cinetina kin, para a indução da calogênese. Fragmentos de folhas foram usados como explantes, esterilizados com solução de hipoclorito de sódio por 40 minutos. Este estudo demonstrou que o melhor resultado para a calogênese foi obtido com as concentrações de auxina/cinetina de 0,1 mg/L / 1mg/L em meio de cultura de Murashige \& Skoog.
\end{abstract}

Unitermos: Sideroxylon obtusifolium, Sapotaceae, planta medicinal, calogênese.

\begin{abstract}
Sideroxylon obtusifolium belongs to the family Sapotaceae which occurs in the Southwest and Northeast of Brazil. It is used in folk medicine due to its anti-inflammatory and hypoglycemic properties. The intense use of its barks and the lack of cultivation of the plant made rare its occurrence in the natural habitat. This study was performed in order to get information about the biomass production of this native species using the techniques of plant tissues culture. The Murashige \& Skoog (1962) and Gamborg et al. (1968) culture media containing auxin 2,4dichlorophenoxyacetic and kinetin kin were used for callus induction. Fragments of leaves were used as explants and sterilized with sodium hypochlorite for 40 minutes. The best outcome for callus induction was obtained with concentrations of auxin/kinetin of $0.1 \mathrm{mg} / \mathrm{L} / 1 \mathrm{mg} / \mathrm{L}$ in the Murashige \& Skoog culture medium.
\end{abstract}

Keywords: Sideroxylon obtusifolium, Sapotaceae, medicinal plants, callus induction.

\section{INTRODUCTION}

Sideroxylon obtusifolium is a plant of the Brazilian flora that occurs in different soil types in the savanna. It is threatened with extinction mainly by the extraction of its bark, which is used in the treatment of diabetes. According to the World Health Organization (WHO), 194 million people suffer from this disease worldwide. In Brazil, it is estimated to affect 12 million in the coming years (Diabetes, 2008). The species of the family Sapotaceae are characterized by the diversity of substances resulting from their secondary metabolism, as triterpenes, steroids, tannins, polyphenols besides alkaloids, carotenes, cyanogenic compounds, carbohydrate and fatty acids (Beltrão, 2000; Perfeito et al., 2005; Montenegro et al., 2006; Barbosa-Filho et al., 2008). Studies on medicinal plants used in popular medicine have been performed in order to search for new hypoglycemic drugs (Barbosa-Filho et al., 2005; Cavalli et al., 2007; Menezes et al., 2007; Torrico et al., 2007; Ferreira et al., 2008; Figueiredo \& Modesto-Filho, 2008; Santos et al., 2008). Steroids and triterpenes with hypoglycemic and anti-inflammatory activities were isolated from Sideroxylon obtusifolium (Almeida et al., 1985, Naik et al., 1991). This species presents the following scientific synonymy: Bumelia sartorum Mart, Bumelia obtusifolium Roemer \& Schut and Bumelia rotundifolia Schut. It is used as expectorant and analgesic, according to Filipoy (1994). The fresh fruit is used as food (Schmeda-Hirschmann, 1994). The entire plant is also used against ovarian inflammations and diabetes. A decoction or maceration of a handful in a liter of water. It is drunk "as water" or tea until the symptoms disappear (Agra et al., 2007 and 2008). 
The development of techniques for in vitro cultivation of plants and the mastery over the use of growth-regulating hormones in specific culture media allowed the continued cultivation of plants and callus in laboratory. The study on the cultivation of plant cells since then took different approaches. The callus can be used to regenerate a plant or to study the secondary metabolites of pharmacological interest, mainly of threatened with extinction medicinal plants as "quixabeira". The callus obtained can be used to study the type of cell, to promote cell selection or to organogenesis, somatic embryogenesis and biomass and secondary metabolites production. The growth of callus in different species may be independent of auxin and cytokinin, auxin-dependent, dependent on cytokinins or both (Torres, 1990; Santos et al., 2007). The auxins and cytokinins are the most used growth regulators in plant tissues culture. Based on this information, experiments were performed to obtain the biomass of the tissues of the plant popularly known as "quixabeira".

\section{MATERIAL AND METHODS}

\section{Plant material}

The experiments were performed using explants of $0.5 \mathrm{~cm}$ of fragments of Sideroxylon obtusifolium leaves collected in the orchard of the Laboratório de Tecnologia Farmacêutica from Universidade Federal da Paraíba. The explants went through a process of asepsis and were subjected to sterilization with the $5 \%$ solution of sodium hypochlorite for 40 minutes, then were washed three times in distilled and sterile water.

\section{Experiment - I}

Two culture media, Murashige \& Skoog (1962) and Gamborg et al. (1968), were used for induction of callus. Two growth regulators were added to the medium, an auxin, 2.4-D and a kinetin, KIN, in concentrations of $0.0 \mathrm{mg} / \mathrm{L}, 0.1 / 1 \mathrm{mg} / \mathrm{L}, 0.50$ / $1 \mathrm{mg} / \mathrm{L}$ and 0.25 / .1 $\mathrm{mg} / \mathrm{L}$.

The culture media were distributed in test tubes containing $10 \mathrm{~mL}$ volume of the medium. They were autoclaved under pressure of $1 \mathrm{kgf}$. during 15 minutes. After autoclaving media, the explants were implanted on the medium in test tubes in aseptic chamber with the help of tweezers. The material was transferred to in vitro culture room, where conditions of temperature and photoperiod were controlled by following the rules for in vitro cultivation of plant tissues (Torres, 1990).

\section{Experiment - II}

After the acquisition of callus to the first replanted was performed in order to enhance growth. The callus culture began using the Murashige \& Skoog medium. In this experiment, which was set out to achieve the optimization of the callus culture in the medium indicated by the previous experiment, callus with 30 days of cultivations divided into fragments of $30 \mathrm{mg}$ per tube test were used as explants. Auxin 2,4dichlorophenoxyacetic and kinetin KIN at concentrations of 0.1 / $0.0 \mathrm{mg} / \mathrm{L}, 0.0 / 1.0 \mathrm{mg} / \mathrm{L}, 0.0$ / $0.0 \mathrm{mg} / \mathrm{L}$ and 1.0 / $1.0 \mathrm{mg} / \mathrm{L}$ were used as plant growth regulators.

The completely randomized statistical model with eight repetitions was used.

\section{RESULTS AND DISCUSSION}

To obtain the callus of Sideroxylon obtusifolium, Murashige \& Skoog (1962) and Gamborg et al. (1968) culture media were used in the initial experiment with 2,4-D and KIN growth regulators. In both media, callus induction was observed in the explants of leaves except for the controls. The callus began to appear around the edges of the explant where there was the cutting of the tissue and was also observed at the center of the explant. Callus obtained in the Gamborg et al. (1968) medium were friable and whitish while the ones obtained in the Murashige \& Skoog (1962) medium were compressed and greenish. During their formation, the parameters of swelling of the explants were observed, prior to their appearance. They began emerging from the third week of the deployment of explants in the culture medium. They grew up to 120 days. Table 1 shows the average weight in the culture media used.

Table 1. Callus induction in Gamborg et al. (1968) and Murashige \& Skoog (1962) media.

\begin{tabular}{crc}
\hline $\begin{array}{c}\text { Growth Regulators } \\
\mathrm{mg} / \mathrm{L}\end{array}$ & Gamborg Media & Murashige Media \\
\hline $0.0 / 0.0$ & $0.0000 \mathrm{~d}$ & $0.0000 \mathrm{~d}$ \\
$0.50 / 1.0$ & $0.2851 \mathrm{c}$ & $0.4244 \mathrm{c}$ \\
$0.1 / 1.0$ & $0.4055 \mathrm{a}$ & $0.6206 \mathrm{c}$ \\
$0.25 / 1.0$ & $0.3681 \mathrm{~b}$ & $0.4604 \mathrm{~b}$ \\
\hline
\end{tabular}

In columns, averages followed by the same letter do not significantly differ themselves, in a $1 \%$ probability by Tukey test.

All culture media tested were solid in equal conditions of temperature and photoperiod. The callus induction of this plant depends on the growth regulators. The composition and concentration of hormones in the culture medium were determining factors in the growth of callus. Initially, cellular diversity caused cells to grow differently in shape, pigmentation and metabolism. According to Smith (1992) many of these features are not visible. The data of fresh weight of callus at the end of the culture period were unequal. In the experiment of growth there was a significant decrease in variation of fresh weight until the full stabilization of the culture. This fact indicates the homogenization of culture and the establishment and optimization of the medium, 
setting up a protocol for callus induction and growth of this plant. This study showed that the best outcome for the culture of callus was obtained with the Murashige \& Skoog (1962) medium containing $0.1 \mathrm{mg} / \mathrm{L}$ 2,4-D and $1 \mathrm{mg} / \mathrm{L}$ KIN (Table 2).

Table 2. Average callus growth of Sideroxylon obtusifolium in Murashige \& Skoog (1962) culture medium with 2,4-D and KIN.

\begin{tabular}{ccr}
\hline $\begin{array}{c}\text { Auxin / Kinetin } \\
\mathrm{mg} / \mathrm{L}\end{array}$ & $\begin{array}{c}\text { Initial Average } \\
\text { Weight }\end{array}$ & $\begin{array}{c}\text { Final Average } \\
\text { Weight }\end{array}$ \\
\hline $0.1 / 1.0$ & $0.3004 \mathrm{c}$ & $1.1555 \mathrm{a}$ \\
$0.1 / 0.0$ & $0.4055 \mathrm{a}$ & $1.1372 \mathrm{a}$ \\
$0.0 / 1.0$ & $0.3681 \mathrm{~b}$ & $1.1164 \mathrm{a}$ \\
$0.0 / 0.0$ & $0.2851 \mathrm{c}$ & $0.8763 \mathrm{~b}$ \\
\hline
\end{tabular}

In columns, averages followed by the same letter do not significantly differ themselves, in a $1 \%$ probability by Tukey test.

\section{CONCLUSION}

The experiments conducted to obtain the callus with the aim of producing biomass from Sideroxylon obtusifolium showed that callus induction and obtaining are possible in both culture media (Murashige \& Skoog, 1962 and Gamborg et al., 1968) with 2,4-D and KIN.

The best result was obtained with the medium of Murashige \& Skoog (1962) with the concentration of auxin 2,4-D at $0.1 \mathrm{mg} / \mathrm{L}$ combined with $1 \mathrm{mg} / \mathrm{L}$ kinetin KIN.

The formation of callus did not occur in the absence of hormones. The "quixabeira" is dependent on plant growth regulators.

\section{REFERENCES}

Agra MF, França PF, Barbosa-Filho JM 2007. Synopsis of the plants known as medicinal and poisonous in Northeast of Brazil. Rev Bras Farmacogn 17: 114140.

Agra MF, Silva KN, Basílio IJLD, França PF, Barbosa-Filho JM 2008. Survey of medicinal plants used in the region Northeast of Brazil. Rev Bras Farmacogn 18: 472-508.

Almeida RN, Barbosa-Filho JM, Naik SR 1985. Chemistry and pharmacology of an ethanol extract of Bumelia sartorum. J Ethnopharmacol 14: 173-185.

Barbosa-Filho JM, Vasconcelos THC, Alencar AA, Batista LM, Oliveira RAG, Guedes DN, Falcão HS, Moura MD, Diniz MFFM, Modesto-Filho J 2005. Plants and their active constituents from South, Central, and North America whit hypoglycemic activity. Rev Bras Farmacogn 15: 392-413.

Barbosa-Filho JM, Alencar AA, Nunes XP, Tomaz ACA, Sena-Filho JG, Athayde-Filho PF, Silva MS, Souza MFV, da-Cunha EVL 2008. Sources of alpha-, beta-, gamma-, delta- and epsilon-carotenes: A twentieth century review. Rev Bras Farmacogn 18: 135-154.

Beltrão AES 2000. Metabólitos Secundários Bioativos em Cultura de Tecidos de Sideroxylon obtusifolium Roem \& Schult e Micropropagação de Mentha vilosa Hudson. João Pessoa, Paraíba, 82 p. (Tese de Doutorado) Programa de Pós-Graduação em Produtos
Naturais e Sintéticos Bioativos do Laboratório de Tecnologia Farmacêutica. Universidade Federal da Paraíba.

Cavalli VLLO, Sordi C, Tonini K, Grando A, Muneron T, Guigi A, Roman Júnior WA 2007. Avaliação in vivo do efeito hipoglicemiante de extratos obtidos da raiz e folha de bardana Arctium minus (Hill.) Bernh. Rev Bras Farmacogn 17: 64-70.

Diabetes 2004. Disponível em: <www.diabetes.org.br>. Accessed in March 2008.

Ferreira EB, Fernandes LC, Galende SB, Cortez DAG, Bazotte RB, Hypoglycemic effect of the hydroalcoholic extract of leaves of Averrhoa carambola L. (Oxalidaceae). Rev Bras Farmacogn 18: 339-343.

Ferreira EB, Fernandes LC, Galende SB, Cortez DAG, Bazotte RB, Hypoglycemic effect of the hydroalcoholic extract of leaves of Averrhoa carambola L. (Oxalidaceae). Rev Bras Farmacogn 18: 339-343.

Figueiredo AS, Modesto-Filho J 2008. Efeito do uso da farinha desengordurada do Sesamum indicum L nos níveis glicêmicos em diabéticas tipo 2. Rev Bras Farmacogn 18: 77-83.

Filipoy A 1994. Medicinal plant of the Pilage of Central Chaco. J Ethnopharmacol 44: 181-193.

Gamborg O, Miller R, Ojima K 1968. Nutrient requeriments of suspention cultures of soybean rootcells. Exp Cell Res 50: 151-158.

Menezes FS, Minto ABM, Ruela HS, Kuster RM, Sheridan H, Frankish N 2007. Hypoglycemic activity of two Brazilian Bauhinia species: Bauhinia forficata L. and Bauhinia monandra Kurz. Rev Bras Farmacogn 17: 8-13.

Montenegro LHM, Oliveira PES, Conserva LM, Rocha EMM, Brito AC, Araújo RM, Trevisan MTS, Lemos RPL 2006. Terpenóides e avaliação do potencial antimalárico, larvicida, anti-radicalar e anticolinesterásico de Pouteria venosa (Sapotaceae). Rev Bras Farmacogn 16 (Supl.): 611-617.

Murashige T, Skoog FA 1962. A revised medium for a rapid growth and bioassays with tobacco tissues cultures. Plant Physiol 15: 473-479.

Naik SR, Barbosa-Filho JM, Dhulley JN 1991. Probable mechanism of hypoglicemic activity of bassic acid, a natural product isolated from Bumelia sartorum. $J$ Ethnopharmacol 33: 37-44.

Perfeito JP, Santos ML, López KSE, Paula JE, Silveira D 2005. Characterization and biological properties of Pouteria torta extracts: a preliminary study. Rev Bras Farmacogn 15: 183-186.

Santos AS, Araújo SF, Goulart HF, Caetano LC, Arruda MSP, Santos LS, Santa'Ana AEG 2007. A dehydrorotenoid produced by callus tissue culture and wild plant roots of Boerhaavia coccinea. Rev Bras Farmacogn 17: 538-541.

Santos HB, Modesto-Filho J, Diniz MFFM, Vasconcelos THC, Pereira FSB, Ramalho JA, Dantas JG, Santos EB 2008. Avaliação do efeito hipoglicemiante de Cissus sicyoides em estudos clínicos fase II. Rev Bras Farmacogn 18: 70-76.

Schmeda-Hirschmann G 1994. Plant resources used by the ayoreo of the Paraguayan Chaco. Econ Bot 48: 252258.

Smith RH 1992. Plant tissue culture: Techniques and experiments. Texas AEM University. College Station, Texas. Academic Press, Inc.

Torres AC 1990. Técnicas e aplicações da cultura de tecidos de Plantas. ABCTP/EMBRAPA. CNPH.

Torrico F, Cepeda M, Guerrero G, Melendez F, Blanco Z, Canelón DJ, Diaz B, Compagnone RS, Suárez AI 2007. Hypoglycaemic effect of Croton cuneatus in streptozotocin-induced diabetic rats. Rev Bras Farmacogn 17: 166-169. 